\title{
MIĘDZY TWARZĄ A JAPOŃSKĄ MASKĄ ${ }^{1}$
}

\author{
ESTERA ŻEROMSKA
}

Japońscy bogowie sintoistyczni (kami) mają ludzką naturę. Są bowiem trochę dobrzy i trochę źli. Na stałe zamieszkują niebiańską krainę, ale podczas tymczasowego pobytu na ziemi, wnikają w góry, kamienie, trawy, drzewa, wachlarze... Mogą też wnikać w maski i poprzez nie wpływać na życie człowieka - dodawać mu mocy, chronić przed złem, nagradzać lub karać za jego uczynki. W życiu Japończyków maska odgrywała zatem zawsze ważną rolę i na tyle zrosła się $\mathrm{z}$ ich kulturą, że przeniknęła relacje jednostki ze światem zewnętrznym. Mimo że w ciągu kilku tysięcy lat funkcja maski ulegała zróżnicowaniu, permanentne odzwierciedlenie jej idei w świadomości Japończyków można odnaleźć w języku, psychice, obrzędzie, teatrze czy literaturze.

W Japonii od okresu jōmon (12 000 lat p.n.e.-400 r. p.n.e) znany był zwyczaj wykonywania (często jednorazowych) masek w celu użycia ich w konkretnej sytuacji ${ }^{2}$. Na Okinawie na przykład okazją do wystąpienia w masce były (i są) tańce starego mężczyzny zalecającego się do młodej dziewczyny albo obchody święta zmarłych (obon), kiedy grupa ludzi przebranych za błąkające się po śmierci (niemające swych grobów) duchy zmarłych krąży od domu do domu

\footnotetext{
${ }^{1}$ Szerzej na temat maski japońskiej zob.: Żeromska, E. 2003. Maska na japońskiej scenie. Od pradziejów do powstania teatru nō. Historia japońskiej maski $i$ zwiąanej z nia tradycji widowiskowej. Warszawa: Wydawnictow TRIO (z tej publikacji pochodzą niektóre fragmenty niniejszego tekstu). Por. też: Żeromska, E. 2010. Japoński teatr klasyczny: korzenie i metamorfozy, tom 1: nō, kyōgen. Warszawa: Wydawnictwo TRIO.

${ }^{2}$ Honda, Yasuji. 1987. „Masked performance studies. Their present state and future issues“. W zbiorze: International Symposium on the Conservation and Restoration of Cultural Property. Masked Performances in Asia. 1987. Tokyo: Tokyo National Research Institute of Cultural Properties. 1-12.
} 
i recytuje modlitwę (nenbutsu). Wielu wykonawców robiło maski samodzielnie, używając różnych materiałów, takich jak bambus, muszle, glina, papier, drewno czy kora $\mathrm{z}$ drzew, a po zakończeniu uroczystości przechowywano je lub nieodwracalnie niszczono. Do dziś w wiosce Mishima (prefektura Kagoshima) w czasie każdego święta zmarłych używa się nowych masek. Niektóre z nich przedstawiają bardzo fantastyczne, zwykle wymyślone przez odtwórcę danej postaci, fizjonomie. W Iwami natomiast (prefektura Shimane) w papierowych maskach prezentuje się gwałtowne, żywiołowe tańce bezpośrednio przed rozpoczęciem nocy poślubnej. Obecnie większość japońskich masek jest robiona $\mathrm{z}$ drewna. Ich wykonywaniem zajmują się, jak w przeszłości, tancerze lub profesjonaliści (men-uchi).

Pierwsze japońskie maski odzwierciedlały najprawdopodobniej to, jak ludzie wyobrażali sobie fizjonomie bóstw i były stosowane do celów rytualnych podczas festiwali religijnych (matsuri). Być może z takim przeznaczeniem używano niezwykłej maski z muszli z okresu jōmon ze stanowiska archeologicznego Adaka w miejscowości Jōnan na wyspie Kiusiu (prefektura Kumamoto) oraz wielu masek ceramicznych (domen) z późnego okresu jōmon znalezionych na terenie Tōhoku czy w prefekturach Saitama i Aichi. O powszechności zwyczaju posługiwania się maską przez prahistorycznych mieszkańców archipelagu świadczyć mogą także liczne, odnalezione na tym samym obszarze (na przykład w miejscowości Itakura - prefektura Gunma i w Shinmachi - prefektura Nagano) figurki ceramiczne w maskach, które - jak można się domyślać - przedstawiają postaci szamanów lub szamanek odprawiających rytuał boskiego opętania (kamigakari). O wszechobecności maski w życiu dawnych Japończyków świadczą też różne maski niezwiązane $\mathrm{z}$ tradycją widowiskową, jak na przykład kakemen (maska do zawieszania), przed którymi odprawia się modlitwy albo wielkie kamagami instalowane nad frontowym wejściem do domu w celu ochrony jego mieszkańców przed złymi mocami.

\section{Z dziejów japońskiej maski ,widowiskowej”}

Na początku VII wieku zaczyna się w Japonii rozwój maski drewnianej, która po raz pierwszy dociera $\mathrm{z}$ kontynentu w 612 roku. W tym bowiem roku przybył tam koreański muzyk i tancerz Mimashi (VI/VII), który rozpropagował gigaku - widowisko chińskiego pochodzenia przypominające religijną procesję. Jej uczestnicy poruszali się w rozmaitych maskach. Niektóre z przywiezionych przez Mimashiego egzemplarzy można dziś oglądać między innymi w Muzeum Narodowym w Tokio i w skarbcu Shōsōin w Narze.

Maski gigaku są duże, ciężkie, toporne, konstrukcyjnie przystosowane do osadzania na głowie. Te, które się zachowały do dziś stanowią jedyne świa- 
dectwo na świecie istnienia widowiska, które całkowicie zanikło i w Japonii, i w kraju pochodzenia (Chinach). Do wyjątków należy zwiastujący wszelką pomyślność taniec lwa (shishi-mai), do dziś popularny na terenie całego kraju. Dlatego maski lwa (shishi-men) - największe, najcięższe, zakrywające całą głowę - wraz z wykonywanym w nich (często przez więcej niż jedną osobę) tańcem uniezależniły się od pozostałych masek gigaku i niejako zaczęły żyć własnym życiem, łącząc się z rozmaitymi lokalnymi tradycjami widowiskowymi (na przykład kagura, dengaku) wpisanymi w kalendarz festiwali religijnych (matsuri).

Bardzo atrakcyjne okazało się dla Japończyków sprowadzone z kontynentu widowisko bugaku (VII-VIII w.). Maski niezbędne do jego wykonywania odznaczały się dużym artyzmem. Robiono je, posługując się nieznanymi wcześniej w Japonii sposobami. Z czasem, dzięki systematycznemu doskonaleniu opartej na zagranicznych wzorcach techniki rzeźbiarskiej i malarskiej, Japończycy osiągnęli niebywałe mistrzostwo, które objawiło się przede wszystkim w maskach teatru $n \bar{o}(\mathrm{XIV} / \mathrm{XV})$.

Widowisko bugaku, po dostosowaniu do rodzimych upodobań, stało się ulubioną (świecką) rozrywką arystokratów w okresie od VIII do XII wieku, a później stopiło się ze świątynną i ludową tradycją na terenie całego kraju. Jest też nadal prezentowane podczas niektórych podniosłych ceremonii w Pałacu Cesarskim oraz w nielicznych miejscach (m.in. w świątyni buddyjskiej Shitennōji w Osace ${ }^{3}$ ). Jedynie dynamiczny, będący ważnym elementem bugaku taniec $r y \bar{o} \bar{o}$, prezentowany w masce o tej samej nazwie - podobnie jak tańce lwa (shishi-mai) i starca okina - bywa wykonywany niezależnie od całego widowiska, przy okazji różnych uroczystości świeckich i religijnych, w celu zintensyfikowania modlitwy o deszcz.

Gigaku i bugaku bezpośrednio po dotarciu do Japonii prezentowano albo w formie oryginalnej, albo zmodyfikowanej w taki sposób, żeby Japończykom łatwiej było w nich występować. Początkowo posługiwano się też wyłącznie maskami oryginalnymi, przywiezionymi z kontynentu oraz ich wiernymi kopiami wykonanymi przez Japończyków, którzy dopiero z czasem sprawili, że zaczęły się one odznaczać oryginalnymi, coraz bardziej odmiennymi od pierwowzorów cechami.

Od około IX wieku na japońskiej prowincji zakorzeniało się ludowe, wywodzące się z tradycji sitoistycznej widowisko sato-kagura. Do dziś jest ono powszechne i popularne na terenie całego kraju, co sprawia, że zarówno tańce, jak i liczne, niezbędne do ich prezentowania maski odznaczają się niezwykłą różnorodnością.

\footnotetext{
${ }^{3}$ Szczegółowy opis widowiska bugaku z buddyjskiej świątyni Shitennōji w Osace zob.: Żeromska, E. Japoński teatr klasyczny: korzenie i metamorfozy, tom 1: nō, kyōgen. 87-107.
} 
Prawdziwa popularność powstałego pod koniec okresu Heian (794-1185) buddyjskiego widowiska ennen, które jest złożone z tańców zwiastujących przedłużenie życia, kończy się już na początku okresu Muromachi (1333-1560). Dziś można je zobaczyć zaledwie w kilku miejscach w Japonii, z których największą sławą cieszy się świątynia buddyjska Mōtsuji w Hiraizumi (prefektura Iwate $)^{4}$. Szybki spadek zainteresowania tańcami ennen wynikał najprawdopodobniej z tego, że wiele cech tego widowiska oraz używanych w nim masek wykazuje łudzące podobieństwo do teatru $n \bar{o}$ i farsy kyoggen, które zaczęły się krystalizować pod koniec XIV wieku.

\section{Wygląd maski: od sacrum do profanum}

W czasach prahistorycznych Japończycy utożsamiali maskę z bóstwem, dlatego jej założenie na twarz pojmowali jako przeistoczenie się $\mathrm{w}$ istotę boską. Nawet obecnie wielu maskom, również tym zrośniętym z tradycją widowiskową, przypisuje się te niezwykłe cechy. Masek uznawanych za bóstwa używa się na przykład w prefekturze Nagano podczas festiwalu śniegu (yuki-matsuri), a w czasie procesji religijnej w prefekturze Ehime oddaje się cześć wszystkim trzem odmianom masek okina, które określa się jako trzy święte maski (gosanmen). Zdarza się też, że maskę uważa się za wcielenie boskiego patrona świątynnego.

Wraz z upływem czasu rozwój japońskich widowisk postępował powoli od pierwotnego szamanizmu, poprzez coraz dojrzalsze formy obrzędowe (gigaku, okina, sato-kagura, ennen) po gatunki teatralne, z których uduchowione $n \bar{o}$ pozostaje w znacznie ściślejszym kontakcie z bogami niż bardziej realistyczna farsa kyōgen. Owa stopniowa ewolucja od sacrum do profanum znajdowała odzwierciedlenie w wyglądzie maski, a także w sposobie jej pojmowania i traktowania.

Gliniane i muszlowe maski z okresu jōmon przedstawiają wizerunki bóstw o ludzkich twarzach. Kontrastują z nimi zapożyczone z kontynentu maski drewniane o znacznie bardziej skomplikowanych kszatłtach i zróżnicowanej ekspresji. Dominowały wśród nich wizerunki ptaków i zwierząt (psów, lisów, lwów, małp), które stały się pierwszymi modelami niektórych późniejszych masek, zwłaszcza bogów, demonów i starców. W importowanych do Japonii maskach

\footnotetext{
${ }^{4}$ Szczegółowy opis widowiska ennen z buddyjskiej świątyni Mōtsuji w Hiraizumi zob.: Żeromska, E. Japoński teatr klasyczny: korzenie i metamorfozy, tom 1: nō, kyōgen. 107-121.

${ }^{5}$ Okina - najstarszy w rodzie mężczyzna, który ze względu na swój wiek i rychłą śmierć, jest traktowany jako istota znajdująca się najbliżej niebiańskiej krainy bogów i uznawany za istotę boską (człowiek-bóg).
} 
zwaraca uwagę wyraz powagi, do którego Japończycy zaczęli wprowdzać uśmiech. Stanie się on wyróżniającą cechą masek farsy kyōgen.

Począwszy od VII stulecia do XV wieku, który kojarzy się z powstaniem teatru $n \bar{o}$, postępował proces japonizacji obcych wzorów masek, polegający na zmniejszaniu, upraszczaniu, a zarazem różnicowaniu form i ekspresji twarzy. Drewniana maska japońska, pod względem wielkości, kształtu i budowy, ewoluowała zatem od form dużych, ciężkich, masywnych, zasłaniających całą twarz i zachodzących częściowo lub całkowicie na głowę (gigaku, bugaku, shishi) do form mniejszych, lżejszych, subtelniejszych, nie w pełni osłaniających twarz (nō, kyōgen).

Zwracają uwagę pewne wspólne cechy wielu masek, które pojawiły się w Japonii do XIV wieku (bugaku, tsuina, gyōdō, maska Buddy, demonów, zwierząt). Wśród masek nō natomiast istnieje wielka różnorodność cech i ekspresji. Ich twórcy wzorowali się na konkretnych twarzach i eksponowali te cechy, na których najbardziej im zależało, choć mieli też na względzie treść sztuki. Niezwykłe jest to, że te same utwory dramatyczne są od wieków grane w taki sam sposób i w takich samych (niekiedy nawet w tych samych) maskach.

\section{Ewolucyjna desakralizacja mocy maski}

W czasach prahistorycznych uformowanymi z muszli, gliny (domen) czy bambusa wizerunkami osłaniano twarze nie $z$ chęci ukrycia się przed światem czy dla zabawy, lecz z potrzeby oddania czci bóstwom, z wiary, że szczęście można sobie zapewnić, adresując do nich życzliwe prośby. W tym celu w określonych porach roku zapraszano je do zejścia na ziemię. Podczas tymczasowego pobytu bóstw pośród ludzi starano się zjednywać ich przychylność, prezentując na przykład opisane $w$ mitologii sceny $z$ ich życia. Potrzeba nawiązywania kontaktu z siłami nadprzyrodzonymi była więc głównym powodem, dla którego Japończyk musiał posłużyć się maską.

Pod jej osłoną prahistoryczni Japończycy modlili się o długie, dostatnie życie albo o odstraszenie złych mocy. Osiągali to w stanie ekstazy możliwej dzięki tymczasowej metamorfozie. Niektóre maski (na przykład okina) traktowali jako uosobienie boga.

W widowisku sato-kagura maskę zaczęto traktować jako kami-za (miejsce wstąpienia bóstwa), a jej założenie - jako uroczyste spotkanie z bogiem, z którego radość wyrażano za pomocą tańca-modlitwy. W rozpowszechnionym na terenie północnej Japonii widowisku yamabushi-kagura szczególną czcią otacza się maski lwa (gongen-gashira) z racji przekonania, że czasowo wstępuje w nie bóstwo (gongen) zapewniające ochronę przed złem i pożarami. 
W widowiskach gigaku, bugaku, ennen założenie maski oznacza natomiast akt przeistoczenia wykonawcy (człowieka) w boga lub w inną postać nadnaturalną albo zwierzęcą. Jest więc to czynność bardziej teatralna niż w widowiskach okina i sato-kagura.

Rozwój maski postępował zatem w kierunku utraty znaczenia religijnego i stawania się maską teatralną, oddzieloną od obrzędu - częściowo lub całkowicie. Mimo to w teatrze, zwłaszcza $n \bar{o}$, w pojmowaniu roli maski pobrzmiewają stale echa pradawnych rytuałów obrzędowych, w których najważniejszy był szaman. Powiada się, że w $n \bar{o}$ „zastępuje” go główny aktor (shite) i tym uzasadnia się używania przez niego maski. Jest mu ona potrzebna do przeistoczenia się $\mathrm{w}$ istoty nadprzyrodzone, a także w zwykłe kobiety i mężczyzn. Teatr $n \bar{o}$ po raz pierwszy w dziejach japońskiej tradycji widowiskowej dopuszcza możliwość przeistoczenia się człowieka w człowieka (mężczyzny-aktora w kobietę, starego mężczyzny-aktora w młodego, młodego mężczyzny-aktora w starego). Wcześniej postać realnego człowieka mogła pojawić się na scenie wyłącznie bez maski.

Maska w świecie $n \bar{o}$ staje się przedmiotem swoistego kultu. Przypisuje się jej posiadanie własnej duszy. $Z$ tej racji należy się jej szacunek. Jest on niezbędny również dlatego, że maskę utożsamia się z prawdziwą twarzą aktora. Twarz i maska to jedno. Nie wolno jej zatem traktować w dowolny sposób, tak jak nie powinno się wykraczać poza określony kod postępowania w stosunku do żywej ludzkiej twarzy.

W kyōgen użycie maski zasadniczo nie różni się od użycia w teatrze $n \bar{o}$. Odmienny jest natomiast sposób jej pojmowania. W realistycznej konwencji farsy maska zatraca całkowicie swój boski charakter. Przestaje też być ludzką twarzą. Pojawia się poczucie odrębności. Maska zaczyna być zwykłym rekwizytem, który pozostaje nim nawet po umocowaniu na twarzy.

\section{Pod osłoną maski - przeistoczenie w postać}

Pośród niezliczonych japońskich masek (m. in. kagura, bugaku, ennen, shishi-mai, tsuina, nō, kyōgen) szczególne miejsce zajmują maski starca okina używane w trzyczęściowym, dobrowróżbnym widowisku o tej samej nazwie. Może być ono wykonywane w całości albo fragmentarycznie (obecnie najczęściej wystawia się tylko trzecią część sanbasō), niezależnie lub na początku prezentacji jakiegoś widowiska czy przedstawienia teatralnego (nō, kabuki, jōruri).

W pełnym widowisku okina używa się trzech wersji masek (okina-men) rozpoznawalnych dzięki przymocowanej sznurkiem ruchomej brodzie i różniącym kolorom (biały, cielisty, czarny). Wyjątkowość tych masek polega na tym, że są one utożsamiane $\mathrm{z}$ bóstwem i $\mathrm{z}$ tego powodu traktowane ze szczególną 
atencją, czego wyrazem jest przede wszystkim to, iż zawsze wykonawca tańca pojawia się scenie z odkrytą twarzą i na oczach widzów wkłada maskę. Oznacza to, że - w przeciwieństwie do zwyczaju obowiązującego w pozostałych gatunkach widowiskowych - najpierw ukazuje się on jako człowiek, a dopiero potem, na oczach widzów (lub uczestników obrzędu) osłania własną twarz - swoją właściwą tożsamość.

Podobna zasada obowiązuje wykonawców (popularnego tylko na północy głównej japońskiej wyspy Honsiu) tańca lwa (gongen-mai). Zanim włożą oni wielką, zakrywającą całą głowę maskę, czyli zanim przeistoczą się w zwierzęcą postać, przez chwilę tańczą „prywatnie” jako zwykli ludzie. Znane są jednak odwrotne sytuacje, kiedy wykonawca tańca lwa najpierw pojawia się w kompletnym przebraniu, a w trakcie występu nagle odsłania twarz, zdradzając tym samym, kim jest w rzeczywistości. Naoczny świadek transformacji człowieka (tancerza, aktora) w nierzeczywistą postać (lub odwrotnie) albo - jak by powiedział Eugenio Barba - świadek przekształcenia ciała „prawdziwego” (własnego) w „ciało fikcyjne” odnosi wrażenie, że doświadcza czegoś bardzo ważnego, uświadamia sobie istotę misterium, w którym uczestniczy.

W Japonii przez długie wieki ukrywano twarze za maskami, parawanami, papierowymi drzwiami. Głos nie był objęty tabu, mógł być słyszalny, ale wzrok często napotykał na różne przeszkody nie do pokonania. Nigdy nie ujawniano też własnej indywidualności. Dopiero w dobie telewizji, wraz z nastaniem kultury twarzy ważniejsze stało się to, co realne i widoczne niż wartości tajemne (yūgen), niewysłowione. O tym jednak, że Japończycy w głębi serca nie przestali tęsknić za tradycyjnymi wartościami świadczyć może nie tylko żywotność rodzimych widowisk, ale również świadomość integralnie z nimi związanej maski oraz jej symboliczna obecność w psychice, obyczaju, w literaturze.

\section{Między twarzą a maską, między awersem a rewersem}

Japońska maska psychiczna jest oznaką harmonii przeciwieństw, a nie - jak zwykło się rozumieć - oznaką hipokryzji czy frontu walki dobra ze złem. Japońska maska jawi się jako pojednanie. Aby to zrozumieć, należy przeniknąć zakamarki duszy Japończyka i zapoznać się ze szczególną terminologią z pogranicza psychologii i estetyki. Należy też pamiętać o konieczności otwarcia się na specyfikę zupełnie innej kutury, o czym pisze na przykład Ruth Bennedict (1887-1948) w Chryzantemie i mieczu:

Wiara Zachodu w spójność ludzkiego zachowania nie zawsze oczywiście jest usprawiedliwiona, niemniej spójność taka nie jest złudzeniem. W większości kultur, pierwotnych $i$ cywilizowanych, mężczyźni $i$ kobiety postrzegaja siebie samych jako określone 
osoby. Jeśli pragna władzy, ocean porażki lub sukcesu zależy od podporzadkowania innych swojej woli. Jeżeli chca być kochani, bezosobowe stosunki sa dla nich źródtem frustracji. $[\ldots]$

Ludziom z Zachodu trudno jest dać wiarę, że Japończycy nie zmieniaja swego zachowania kosztem własnej psychiki. Nasze doświadczenie nie obejmuje tak krańcowych zwrotów. Jednak to, co uważamy za przeciwieństwa u Japończyków, wyrasta z ich światopogladu tak samo jak to, co wydaje nam sie jednolite, zakorzenione jest w naszym. Bardzo ważne, żeby ludzie z Zachodu zdali sobie sprawę, że wśród „kręów”, na które Japończycy dziela życie, nie ma „kręu zła”. Nie znaczy to, że nie potrafa oni określić, co jest dobrym, a co złym postepowaniem. Chodzi o to, że z ich perspektywy życie ludzkie nie stanowi sceny walki dobra ze złem; egzystencja ludzka jest dramatem bezustannego dążenia do równowagi między sprzecznymi wymaganiami poszczególnych „kręgów” $i$ między wykluczającymi się nawzajem sposobowi postępowania, przy założeniu, że każdy krąg $i$ każdy sposób jest sam w sobie dobry. Jeżeli każdy kierowałby się rzeczywiście instynktem, wszyscy byliby dobrzy ${ }^{6}$.

Różnice kulturowe, które opisuje Ruth Bennedict objawiają się nieuchronnie w sferze pojęciowo-werbalnej. Polskie słowo maska (ang. mask) jest jedynym odpowiednikiem kilku japońskich terminów. Najbardziej ogólnym, obejmującym każdy rodzaj maski (nie tylko japońskiej), jest wyraz kamen zapisywany dwoma ideogramami chińskimi. Pierwszy z nich $(\mathrm{ka}-)$ oznacza tymczasowość, chwilowość, prowizoryczność. Drugi znak (-men), po japońsku odczytywany także jako omote, jest bardziej wieloznaczny i w zależności od kontekstu można go rozumieć jako stronę zewnętrzną, maskę, awers maski, twarz. Kamen to zatem prowizoryczna twarz, zewnętrzna (widoczna) strona maski, czyli jej awers. Słowo men bywa używane (z grzecznościowym prefiksem o-) wymiennie z kamen, ale najczęściej występuje jako drugi człon terminu będącego nazwą poszczególnych rodzajów czy typów masek, na przykład, domen (maski ceramiczne okresu jōmon), kagura-men (maski kagura) czy kyōgen-men (maski farsy kyōgen).

W świecie japońskich widowisk nie zdarza się, jak w tradycji europejskiej, aby maska podkreślała indywidualność postaci lub przedstawiała jej oryginalną twarz ${ }^{7}$. Japońska maska może służyć odpersonalizowaniu wykonawcy, neutralizacji ekspresji twarzy, podkreśleniu stereotypowości postaci, a także jej odrealnieniu.

O masce $n o \overline{~ n a ~ p r z y k ł a d ~ p o w i a d a ~ s i e ̨ ~ p r z e w a z ̇ n i e ~ o m o t e ~ l u b ~(o) m e n . ~ P r z e c i-~}$ wieństwem tych terminów jest słowo ura (inaczej: urate) oznaczające to, co ukryte pod powierzchnią, za twarzą, za maską, czyli jej rewers.

\footnotetext{
${ }^{6}$ Benedict, R. 1999. Chryzantema i miecz. Wzory kultury japońskiej. Warszawa: Państwowy Instytut Wydawniczy. 184-185.

${ }^{7}$ Hoff, F. 1987. "Masked Drama East and West". W zbiorze: International Symposium on the Conservation and Restoration of Cultural Property. Masked Performances in Asia. 13-14.
} 
Realcja ura i omote, odniesiona do stosunków międzyludzkich, wskazuje na zależność postaw człowieka i wypowiadanych przez niego słów od kontekstu sytuacyjnego. Dla aktora $n \bar{o}$ na przykład takim kontekstem staje się maska nieubłaganie nieruchoma drewniana płaszczyzna, która, oddzielając go od światła, ogranicza do minimum kontakt wzrokowy z otoczeniem i zmusza do poruszania się w niemal w całkowitej ciemności.

Powiada się, że teatr $n \bar{o}$ jest zamknięty w masce. Tę sytuację można różnie interpretować. Kanze Hisao (1925-1978) - już protagonista (shite), twierdził na przykład, że aktor $n \bar{o}$ po włożeniu maski na twarz jest skazany na rywalizację $\mathrm{z}$ tym odrębnym bytem, który staje się jego twarzą. Twierdził też, że na scenę wychodzi głównie po to, żeby nam tę rywalizację pokazać.

Ocena Kanze Hisao wynika z praktycznego, przykrego dla aktora doświadczenia występowania w masce. Tymczasem Sakabe Megumi, spoglądając na tę kwestię okiem badacza, koncentruje swą uwagę na tym, że w Japonii gdzie nigdy nie stosowano ani wyraźnego rozróżnienia między JA a INNYM (INNYMI) i nigdy nie zarysowywano wyraźnej granicy między przedmiotem a podmiotem - maska oraz idea maskowania nie ma nic wspólnego z europejskim pojmowaniem dualizmu. $\mathrm{W}$ teatrze $n \bar{o}$ odzwierciedleniem takiego rozumowania jest sposób, w jaki aktor wkłada maskę. Robi to tak, że nieosłonięty dolny fragment brody sprawia wrażenie, jakby był przedłużeniem maski, a linia graniczna między jej drewnianą krawędzią a twarzą była niemal całkowicie zatarta i niedostrzegalna, dzięki czemu widz może ulegać złudzeniu, iż maska jest właściwą twarzą aktora, a twarz - rewersem maski.

Sakabe Megumi, opisując to, co się dzieje między twarzą a maską japońską, posługuje się przykładem z pogranicza językoznawstwa (dot. struktury języka japońskiego), psychologii i obyczaju, co można rozszerzyć o przykład z zakresu estetyki, a nawet architektury.

Sakabe przygląda się odwiecznemu w Japonii pojmowaniu relacji między przestrzenią (sferą) prywatną a przestrzenią (sferą) publiczną, czyli między zachowaniem jednostki $\mathrm{w}$ sytuacji, kiedy bez skrępowania może być sobą, a zachowaniem tej samej osoby $\mathrm{w}$ obecności ludzi. Jest to język bezosobowy (muninshō), tak jak bezosobowe są relacje międzyludzkie. Wielu cudzoziemców często ze zdumieniem zwraca uwagę na tę cechę mentalności (obyczajowości) Japończyków, którzy chętnie zastępują zaimek osobowy ja trzecią osobą gramatyczną (niekiedy wskazując jednocześnie palcem na siebie) i w ten sposób nabierają dystansu do samego siebie. W takim kontekście staje się zrozumiałe, dlaczego Zeami (1363-1443) - twórca i teoretyk teatru $n \bar{o}$ - przywiązywał wielką wagę do tego, aby aktor potrafił spoglądać na siebie od wewnątrz $\mathrm{i}$ - jak widz od zewnątrz, dzięki czemu może być całkowicie obiektywny - może być własnym przyjacielem i wrogiem. 
Zgodnie z tym rozumowaniem pośrednikiem między światem wewnętrznym (ura) i zewnętrznym (omote) staje się maska. Na przykład we wspomnianym, popularnym na północy Japonii (Tōhoku) tańcu lwa (zwanym tam gongen-mai) ikonograficznym symbolem pośrednictwa jest lew, który choć stanowi niewątpliwe zagrożenie dla człowieka, to w określonych sytuacjach może go ochronić przed złem, o czym wiadomo z mitologii chińskiej i japońskiej. Wynika z tego ambiwalenta prawda: nawet najsilniejszy obrońca może okazać się śmiercionośnym napastnikiem. Wynika ponadto, że omote, a zatem to, co znajduje się na powierzchni i jest widoczne, jest zupełnie inne niż ura, czyli to, co kryje się pod powierzchnią i pozostaje niewidoczne.

Relację zachodzącą między twarzą i japońską maską można też postrzegać jako odzwierciedlenie jedności między ura (tył, tylną stronę) i omote (przód, przednia strona). W kulturze Zachodu tył i przód postrzega się wprawdzie całkowicie rozłącznie, jako antonimy, ale w Japonii ura i omote są zwykle kojarzone w zgodną parę, ponieważ - podobnie jak pierwiastki yin i yang - nie są to przeciwieństwa, lecz strony (pojęcia) wzajemnie się dopełniające. Na przykład wyrażenie ura-o yomu (dosł. czytać to, co jest z tyłu) oznacza umiejętność odczytywania (w tekście pisanym lub wypowiedzi ustnej) ukrytych sensów. Umiejętność ta nie jest jednak tym samym, co - jak się po polsku mówi - czytanie między wierszami (w domyśle tego, co jest mniej ważne lub tego, co chciało się ukryć). „Czytanie tyłu” należy raczej rozumieć jako sugestię, że ukryty za omote tył (ura) jest równie ważny. $\mathrm{Z}$ tego wynika, iż to, co niewidoczne (ura) jest równie ważne jak to, co widać (omote).

Japończycy powiadają również Hito-no kokoro-no ura-o yome! (czytaj tył ludzkiego serca; czytaj to, co człowiek ma na myśli). I to wcale nie oznacza, że jakoby słowa przeczą temu, co się faktycznie myśli i czuje. Oznacza to jedynie, że należy wsłuchiwać się w ludzkie intencje i mocą empatii penetrować serce drugiego człowieka, przenikać jego właściwe pragnienia i być otwartym na jego potrzeby.

$\mathrm{Na}$ Zachodzie dziwnie brzmią sparafrazowane słowa pewnego współczesnego biznesmena $\mathrm{z}$ Osaki:

Nie jest trudno czytać ",tyt ludzkiego serca” (odczytywać to, co drzemie we whętrzu cztowieka). Trudno jest czytać „tyt tyłu”, ponieważ tym tyłem jest front, czyli ludzka twarz.

Z tej wypowiedzi wynika, że ura i omote tworzą zamknięty obwód, krąg powstały z objawiającej się po obu stronach istoty rzeczy (hara). Ura dopełnia omote podobnie jak - zgodnie z zasadą yin-yang - światło przenika i dopełnia mrok, a mrok przenika i dopełnia światło. Również odnoszące się do relacji człowieka ze światem (z otoczeniem) pojęcia honne i tatemae nie kojarzą się Japończykom z dwulicowością i zakłamaniem, chociaż cudzoziemcy, często BŁĘDNIE postrzegając je w sposób dualistyczny w kategoriach etycznych do- 
bra i zła, prawdy i kłamstwa, nie tylko nacechowują je moralnie, ale czynią $\mathrm{z}$ nich niemające $\mathrm{z}$ sobą nic wspólnego antynomie. Tymczasem w rzeczywistości honne (dosł. prawdziwy korzeń) oznacza prawdę wewnętrzną i jest odpowiednikiem ura, a tatemae (dosł. to, co jest z przodu) oznacza „prawdę zewnętrzną” $\mathrm{i}$ jest dopełniającym honne odpowiednikiem omote. Wymiernym efektem postrzegania dwóch przenikających się wzajemnie aspektów (stron) tej samej rzeczywistości jako aspektów (stron) dopełniających się, a nie sobie przeciwstawnych jest japoński syndrom udzielania odpowiedzi „tak, ale”, „tak, zgadzam się, ale", do czego większość cudzoziemców z Zachodu nie jest w stanie się przyzwyczaić. Europejczyk czy Amerykanin interpretuje bowiem honne jako „prywatne ja”, a tatemae - jako (nie zawsze tożsame z honne) „publiczne ja”, czyli jako dwie strony tego samego medalu, które nie tylko nie mają z sobą styczności, ale są ze sobą sprzeczne. Tymczasem Japończyk dostrzega honne i tatemae poza monetą i dlatego uważa, że bez trudu mogą się one zamieniać miejscami lub wzajemnie przenikać.

Pomiędzy honne i tatemae jest $m a$ - przestrzeń, która dzieli i zbliża zarazem, podobnie jak okalająca tradycyjny japoński dom weranda engawa sprawia, że znajdując się na niej, przebywa się w przestrzeni wewnętrznej domu (uchiwa), ale jednocześnie pozostaje się w ogrodzie - kręgu zewnętrznym (soto). Następuje przenikanie bycia w środku i bycia poza nim. Przenikanie to musi odbywać się z zachowaniem równowgi. Nie oznacza to jednak, że w określonych sytuacjach nie jest możliwe posługiwanie tylko jedną prawdą - albo honne, albo tatemae. Ograniczanie się wyłącznie do jednego kręgu jest typowe dla sposobu odnoszenia się do cudzoziemców. Japończycy traktują ich jak ludzi z zewnątrz (sotomono) i dlatego zwykli okazywać im wyłącznie prawdę zewnętrzną (tatemae), utrudniając porozumienie, choć osiągnięcie go wymaga wzajemnej otwartości i podpowiadania sobie, jak w codziennych zachowaniach odczytywać całkiem odmienne kody kulturowe. Problem ten można zilustrować na przykładzie twórczości Endō Shūsaku (1923-1996), japońskiego pisarza katolickiego. Zasłynął on między innymi jako autor Iesu-no shōgai (Żywot Jezusa, 1973). Oto kilka cytatów ${ }^{8} \mathrm{z}$ tej powieści świadczących o tym, że Japończykowi trudno jest się przestawić na zachodni, jednoznacznie logiczny, „czarno-biały” sposób myślenia:

Wierzyć, mając wątpliwości co do istnienia Boga, nie oznacza bycie złym chrześcijaninem. Bo przecież caly nasz los sktada się z 99 procent watpliwości i tylko z 1 procenta pewności.

Los oznacza również umieranie w momencie, kiedy się mówi, że nie chce się umierać”.

${ }^{8}$ Wszystkie trzy cytaty przytoczono za: Matsumoto, Michiro. 1988. The unspoken way. HarageI silence in the Japanese business and society. Tokyo/New York: Kodansha International. 65-66 (tłum. E. Żeromska). 
Od dawna deklaruję się jako chrześcijanin, ale szczerze mówiąc, ani Biblia mnie nie inspiruje, ani nie wydaje mi się, żeby chrześcijaństwo byto tym, $w$ co powinienem wierzyć. Pozostaje jednak przy tej religii z dwóch powodów. Po pierwsze dlatego, że nie miałem innego , ubrania”. Nie miatem wyboru, bo to ubranie dostatem od matki. Po drugie bytbym ostatnim niegodziwcem, gdybym pozbyt się „ubrania”, które nosiła też moja ukochana matka!

Z tych krótkich fragmentów wynika, że bohater utworu ma wątpliwości co do wyznawanej przez siebie wiary. Na zewnątrz (tatemae) zdaje się być chrześcijaninem, ale w głębi serca (honne) pozostaje buddystą. Taka ambiwalenta postawa prowokuje do ostrej krytyki czytelnika wychowanego w kręgu kultury zachodniej. Tymczasem wielu Japończyków postrzega takie rozterki z pełnym zrozumieniem i uznaniem jako przejaw naturalnej, ukrytej we wnętrzu (honne) niedoskonałości ludzkiej, której szczere ujawnienie (hara-o waru-dosł. rozciąć brzuch) zasługuje na uznanie.

Musi być zachowana równowaga między honne i tatemae. Ludzie przesadnie zorientowani na tatemae są za bardzo oddaleni, czyli za bardzo mizukusai (dosł. odległy; traktowanie ludzi z kręgu wewnętrznego tak jakby byli z zewnątrz), ale ludzie przesadnie zorientowani na honne są zbyt koleżeńscy w stosunku do innych i robią wrażenie zamkniętych i są traktowani z podejrzliwością nawet wtedy, gdy w rzeczywistości nic przed światem nie ukrywają.

$$
* * *
$$

Na scenie teatru $n \bar{o}$ spotykają się duchy zmarłych z żywymi ludźmi, pojawiają się bóstwa i wyimaginowane zjawy, w trakcie trwania tej samej sztuki protagonista (shite) zmienia maskę, aby ukazać dwa oblicza tej samej postaci. Nie musi w tym celu odsłaniać własnej twarzy, ponieważ poprzez maskę dochodzi do pojednania emocjonalnego - do odpędzenia złych duchów, do uspokojenia oszalałej z bólu i żądnej zemsty kobiety, do okiełznania demona nienawiści, do wybaczenia...

\section{Bibliografia}

Benedict, R. 1999. Chryzantema i miecz. Wzory kultury japońskiej. Warszawa: Państwowy Instytut Wydawniczy.

International Symposium on the Conservation and Restoration of Cultural Property. Masked Performances in Asia. 1987. Tokyo: Tokyo National Research Institute of Cultural Properties.

Matsumoto, Michiro. 1988. The unspoken way. HarageI silence in the Japanese business and society.Tokyo/New York: Kodansha International. 64-68.

Żeromska, E. 2003. Maska na japońskiej scenie. Od pradziejów do powstania teatru nō. Historia japońskiej maski i zwiąanej z nią tradycji widowiskowej. Warszawa: Wydawnictwo TRIO.

Żeromska, E. 2010. Japoński teatr klasyczny: korzenie i metamorfozy, tom 1: nō, kyōgen. Warszawa: Wydawnictwo Trio. 